\title{
Analyzing Stock-Bond Correlation in Emerging Markets
}

\author{
Qurat ul Ain ${ }^{1, *} \&$ Danish Ahmed Siddiqui ${ }^{1}$ \\ ${ }^{1}$ Karachi University Business School, University of Karachi, Pakistan \\ *Corresponding author: Karachi University Business School, University of Karachi, Pakistan. \\ E-mail: quratulainehtesham@gmail.com
}

Received: September 3, 2019 Accepted: September 21, 2019 Published: September 25, 2019

doi: 10.5296/rae.v11i3.15390 URL: https://doi.org/10.5296/rae.v11i3.15390

\begin{abstract}
This study investigates stock-bond correlation in 17 countries of emerging markets during 2011 to 2018 using monthly price data. Data was analyzed using ARCH-LM test, GJR GARCH and Multivariate GARCH type Asymmetric DCC model. Findings of this paper revealed that sequence of return series are stationary containing white noise error, past return volatilities do not have the ability to predict future volatilities and conditional volatility is higher and negative momentum of the market increase the correlation of stock and bond in a country or vice versa and hence increase the diversification benefit for asset allocation in a portfolio construction and provide hedging assets characteristics among countries and it is found that there is a comovement between stock and bond in a country of emerging markets.
\end{abstract}

Keywords: Correlation, ARCH-LM, GJR-GARCH, ADCC, Asymmetric, Heteroscedasticity, volatility, uncertainty, EM 


\section{Macrothink}

\section{Introduction}

\subsection{Background to the Study}

This paper investigates the stock and bond relation of various countries of emerging markets. Stocks and Bonds play an important role for investment and portfolio making decision. These two financial asset classes correlation can be effected because future cash flows and discount rate changes due to economic circumstances. During inflation, stock and bond correlation is positive, when inflation is high, it influences future cash flows as a result of changes of discount rate.

Economic and monetary policy unpredictability leads to "flight to quality" phenomena which means the periods of high uncertainty increases the price of bond market as compared to stock market and their correlation is weaker even negative. This is the phenomena of transfer of money to bond market when risk of stock market is high. During economic expansion, stock market outperforms while in economic contraction bond market perform well. Positive stockbond correlation occur when easing monetary policy. In the long run when macroeconomic conditions are similar, stock and bond move in the same direction and exhibits "equity like" properties especially in emerging markets. Financial market uncertainty mostly influences stock-bond correlation and investors rebalances their portfolio when stock market uncertainty is high. Investors' higher frequency of trading decreases the prices of stock and increases the prices of bond, during economic downturn bust investor's invest more in risky assets which causes negative stock-bond correlation. Stock and bond correlation is useful for hedging each other as bonds seems to be a safer assets as compared with stocks which is classified as risky assets class. Stocks hedge the inflation risk involve in bonds and bonds hedge economic risk associated with stocks.

Now a days stock-bond correlation is gaining more attention in emerging markets because investors is seeking for portfolio diversification and government bond of emerging markets is the second largest financing sources since 1990's and its appealing for investors for investing because liquidity and transparency in emerging markets also increases.

Some early studies outline the Fed model to investigate the relationship of stock and bond markets (Yardeni, 1997). This model implies that P/E ratio of stocks of emerging markets is likely to be the reciprocal of the bond yields to maturity hence generating a positive relation between stocks E/P ratio and bond yields. So whenever the differential is created investors reallocate the portfolio from lower investment to higher investment return through gross substitutes (Tobin, 1982).

\subsection{Problem Statement}

The purpose of the study is to understand stock-bond correlation in emerging countries. Emerging markets are riskier and uncertainty of the market is high. Investors are investing in riskier market in a way to earn higher returns. Stock and bonds are two important assets in prospects of good investment. If investors' have the ability to predict future co movement of stock-bond, he can benefit through using different strategies. Historical evidence reveal that stock-bond correlation in the end of 1990's is positive and onwards is negative. During global 


\section{Mll Macrothink}

Research in Applied Economics

ISSN 1948-5433

2019, Vol. 11, No. 3

financial crisis (2007) investor's sell off their equity investment and shift their investment to bond for better return as their correlation is negative and investors quickly take advantage of this situation and this phenomena is said to be "flight to safety" phenomena where as in 2007 financial crisis emerging markets financial indicator became extremely correlated and stock market reached its top. As investors became risk averse and rapidly reallocated portfolio to safer assets (Nathaniel Frank, 2009). Movement of stock and bonds is dependent upon economic factors like higher inflation which tend to rise interest rate and also raise the dividends and reduce the correlation between them, while in economic growth they have positive effect on correlation between stock and bond. However, investors demand premium for higher uncertainty related to stocks prices and bond yields. Some prior events evidence reveal that stock-bond correlation was high during financial downturn likewise 1930's depression, 1970 recession, 1987 stock market crash, 1990 Asian and Russian financial crisis, early 2000's recession, European sovereign debt crisis and global financial crisis (2007) because of adverse event happened and it's responsible for stock market dispersions that weakens the stock's price value and increase the risk premium and it is notable that bonds premium decreases during economic contraction hence these conditions influencing the stock bond correlation rise (Ewan Rankin, 2014) and remaining period (e.g. low inflation, low growth, volatility, weak equity) stock bond correlation becomes negative. Negative correlation gives the benefit to bonds best hedging characteristics and "flight to quality" phenomena consistent with negative stock bond correlation. Emerging markets are more volatile and its assets have equity like characteristics and they payoff higher return and investors can diversify their risk whenever financial crisis occur, EM assets' value quickly decline as compared with developed markets. This research paper analyzes stock-bond correlation in order to identify the impact of market shocks, volatility of EM on stock and bond.

\subsection{Gap Analysis}

(Valentyn Panchenko, 2009) Conducted a research to identify the market integration impact between stock and bond varying over time by using parametric and non-parametric approach on sample data of 18 emerging markets and found that opening market integration with rest of the word negatively impact as it increases the requirement of stocks whereas bonds demand decline or become unchanged, hence segmentation of market risk premium reduces and provides diversification benefit to investor. Non parametric approach is most suitable for determining stock-bond co-movement. Another research investigates the stock-bond correlation in U.S. markets (Thomas C. Chiang J. L., 2009) and found that stock-bond correlation is negatively correlated with financial market uncertainty and positively correlated with short term rates and real income growth and depends on macro-economic factors during the time span 1996 to 2008 .

Examined financial market uncertainty and stock-bond correlation of BRIC nations on sample period from January 2003 to July 2010 (Marcelo Bianconi, 2013) and their research illustrated that worldwide financial crisis in US affected BRIC countries of Brazil, Russia and conditional correlation volatility also increased and became inversely correlated to stock and bond after this crisis and bond market reacted favorable in very short period of time except India and the stock market of China showed less response with reaction to financial crisis in US whereas in 
long period US financial distressed only bond market of BRIC countries reacted and when comparing with combine influence it showed more association of stock and bond of BRIC nations rather than to the crisis. This paper evidence that after financial distress volatility and disturbance of the market increases.

Another study analyzed six developed markets (Canada, France, Germany, Italy, United Kingdom and United States) stock-bond correlation during 1992 to 2011 and examined structural changes over a period of time and observe that when economy is growing, the markets showed positive correlation or vice versa. Financial market uncertainty (S\&P-500) and conditional variance indicated negative stock-bond correlation consistent with "flight to safety" phenomena whereas, positive correlation with crisis in bond market and stock and bond both move in the same direction. Whenever financial crisis occurred, it increased the spread of Tbills and default risk spread causing negative relationship of stock and bond across different countries. "Flight to quality" phenomena was consistent with financial market uncertainty and bond market spread and this demonstrated that investors want to add good investment in their portfolio and shift their allocation from stock to bond for higher return (Thomas C. Chiang J. L.-Y., 2015).

Many previous researches identified stock-bond correlation over a period of time and analyzed stock-bond relationship during financial crisis but no research examined stock-bond comovement in emerging markets as a whole and identified the pattern of stock and bond and market shocks impact on stock-bond correlation,- either good or bad.

\section{Literature Review}

Following are the some recent studies which provide evidence of existence of co-movement, correlation and volatility over the period of time between indices and government bonds in the market.

(Hossein Asgharian, 2015) Investigated the relation by using mixed data sampling (MIDAS) and analyzed how macroeconomic uncertainty influence stock and bond correlation in the long run and their volatility. Their results show that flight to quality phenomena and macroeconomic variable and alternative macroeconomic like GDP growth results are similar and effect to volatility is increasing over time. Out of sample results did not exhibit to explain macroeconomic uncertainty.

(Nebojsa Dimic, 2016) Analyzed stock-bond correlation of 10 emerging markets and applied the wavelet analysis approach over different time period. In short run, stock-bond changes sign rapidly and shows negative correlation during crisis period and consistent with "flight to quality phenomena" and in the long run stock-bond having positive correlation shows "equity like" properties and only considers country specific risk. Their results also suggest that easing monetary policy is helpful for explaining stock and bond correlation association. Inflation is also one of the factor for influencing variation in stock-bond correlation. Bond prices reacted negatively with increase of inflation and high inflation also adversely effected the stock prices and in the long run showed a positive relationship between US and emerging markets. This 
study is helpful for asset allocation decisions over the time period while explaining global crisis uncertainty in stock market plays a more significant role than bond market.

(Libing Fang, 2018) analyzed investor's expectation regarding increase or decline of trading activities in financial market which effect investor's sentiment and uses composite index based on how investors' sentiment effect stocks return when investors sentiment regarding stocks (small stocks, young stocks, high volatility stocks, unprofitable stocks, non - dividend paying stocks, extreme growth stocks, and distressed stocks ) return is high their return is relatively low or vice versa (Malcom Baker, 2006) and measures long run U.S. stock-bond correlation by using DCC-MIDAS model which determined asset allocation decisions, evaluating portfolio weighs and performance when time varying and does not affect investor's sentiment during crisis period i.e. 1997 Asian financial crisis and 2008 Global financial crisis while stock-bond correlation decreases. Since investors are risk averse it is suggested that policy makers taking account of investor's sentiment index its helpful for improving the portfolio performance and risk management.

(Xia-Ming Li, 2015) Examined economic policy uncertainty (EPU) shocks on stock-bond correlation in the US. Their findings suggest that positive shocks of uncertainty decrease the correlation and when controlling structural changes because of introduction of euro , asymmetric effect on non EPU index i.e. negative shock of EPU impact on post euro stockbond correlation or vice versa and innovation in historical EPU is that negative shocks raise the stock-bond correlation or vice versa.

(Fu-Lai Lin, 2018) Used wavelet analysis to find out both long term and short term stock-bond relation during 1988 to 2014 . The study under consideration analyzed daily stock and bond returns of US market which shows that since 1990's their relationship changed dramatically in the long run and time varying changes relied on macroeconomic conditions and financial market uncertainty. During crisis period stock-bond relation significantly showed a positive relation. Stock-bond return relation relied on two economic factor i.e. discount rate and short rate and they both had positive effect on short term as well as long term stock-bond relation and also showed positive impact during favorable economic conditions. This paper also analyzed volatility index effect which shows adverse impact on stock-bond relation on daily, weekly, quarterly and annual frequencies and uniform with findings of "flight to safety" phenomena from (Robert Connolly, 2005) discover that future correlation of stock and bond had negative relation with stock market and during volatility, the stock turnover increases and the bond return is large and (Lieven Baele, 2010) found that stock-bond correlation is positive in the end of 1980's and afterwards their correlation is negative and when they explored risk premium proxy approach they also found negative stock-bond correlation, their research indicated that "flight to safety" did not fit in their model. Hence frequencies results are varied of TED and crisis dummies so employed continuous wavelet analysis of both high and low frequency data simultaneously. During long run crisis period negative relation prevailed, while in the short run positive relation was found. This study is considerable for investor's for asset allocation, portfolio rebalancing and understanding the benefits of portfolio diversification. In times of crisis stock-bond correlation was found to be positive which minimized the portfolio diversification. 
(Harumi Ohmi, 2015) This study analyzed long run trends of stock-bond return correlation and using smooth transition regression model i.e. STR of three transition variables (VIX, short rate and yield spread) of (Nektarios Aslanidis, 2012). It also examined the US, Germany and UK stock-bond correlation and observed declining trend of three countries. Some earlier studies established DCC model of Engle (2002) which recommended that financial stock-bond correlation returns are generally hugely serially correlated. In this article, extending STR model by applying AR (1) terms which is extremely significant to all countries. Hence change in stock-bond correlation occur steadily as compared to previous economic variable prediction. Results of extended transition variable are consistent with previous studies (Nektarios Aslanidis, 2012) in which stock-bond correlation was studied through smooth transition patterns using extreme data frequency and result of the study indicated that using multiple transition variables gives more accurate empirical findings as compared with single transition variables. Hence large positive stock-bond correlation was found as a result of increasing level of short rate and yield spread whereas large negative stock-bond correlation indicated higher volatility index (VIX) and was statistically significant for all countries. VIX is the most influencing transition variable for explaining stock-bond correlation as well as time trend component through in sample analysis finest model selection based on SIC and AIC where as in out of sample analysis transition variable i.e. VIX, time trend indicating other models. During declining trend, short rate and yield spread did not have explanatory power while upward trend explain by transition variables and consistent with stock-bond correlation higher in developed markets (DM) than in emerging markets using copula model for analyzing short run and long run dependence and when diversification benefits minimized emerging markets have still some advantages because in period of crisis equity market of EM have only country specific risk (Peter Christoffersen, 2012).

According to this study focus to investigating eight advanced market to analyzing the stockbond correlation and interesting determination showed for safer countries having decline trend of stock-bond correlation and for riskier countries i.e. Italy, Portugal and Spain raising correlation particularly during the rise of euro crises. Some earlier studies provide evidence that in the long run stock market move in the same direction diminishes the international diversification benefits and prices of stock decreases for hedging the risk of stocks investor's invest in bond market, thus decreases the stock-bond correlation. Similarly after euro crisis, increase of stock-bond correlation decreases the diversification effect and it leads to "flight to quality" phenomena (Okimoto, 2016)

\section{Conceptual Framework}

(Hossein Asgharian, 2016) studied long run stock bond correlation using mixed data sampling (MIDAS) with the help of dynamic conditional correlation (DCC) and found that long run stock-bond correlation relied on macro finance variable and lagged conditional variance and it indicated that only macro finance variable effect is very smooth on stock-bond correlation but the combine effect of macro finance and conditional variance is slightly volatile and long run stock bond correlation can be estimated through inflation rate, short term rate, industrial 
production, producer confidence and consumer confidence. Growth of economy support higher stock-bond correlation or vice versa.

Another research conducted on stock-bond correlation by (McMillan, 2018) found that stockbond correlation can be used to estimated future outlook of economic growth and market performances. Positive correlation indicate economic expansion that would lead to raised asset prices whereas negative correlation lead to "flight to quality" phenomena and investors transfer assets from stocks to bonds during economic contraction. Positive or negative correlation illustrate market upward and downward performances and also macroeconomic variables effect the forecasting of stock-bond correlation. Moreover it is helpful for investors to make strategies for improving portfolio performances and insight view of market interpretation.

(Jian Yang, 2009) Investigating stock and bond relationship over the past 150 years and analyzing macroeconomic impact over the period of time in US and UK. It is observe that when economic growth is in expanding higher correlation and economic growth is tightening lower correlation in US whereas in UK greater correlation is in economic tightening and lower correlation is in expansion of economy and enhancing diversification feature in US for providing bonds as best hedging characteristics for uncertainty in stock market than UK. Stockbond correlation depend on macroeconomic variable i.e. short term rate and inflation rate and suggest that higher correlation is the result of higher inflation or vice versa. In this paper it is verified that UK stock bond correlation is substandard than US and overall follows the same pattern across the time period.

(Robert Connolly, 2005) Explained stock-bond correlation through inflation and stock market uncertainty. Higher inflation describe co-movement of stock and bond whereas larger stock market uncertainty is the result of negative stock-bond correlation and low level of inflation suggest lower correlation and no impact is seen on correlation from macroeconomic conditions. Stock and bond correlation fluctuation is temporary across time period from positive to negative and market uncertainty and inflation expectations are useful for forecasting stockbond correlation.

Emerging markets are more fluctuating market and volatility of the market provide benefit to investor's with trade off higher return for taking higher risk when comparing with developed market they are less volatile and having low diversification benefit whereas low correlation in emerging market is profitable for investors adding assets in a portfolio. Emerging market react with market momentum and move in this direction so it's good for investors who have insight information for reallocating assets in a portfolio. However stocks and bonds both assets prices are volatile in emerging markets and are more riskier in contrast with assets of developed market whereas bonds are considered as safer assets because of less uncertainty and hedging characteristics against stocks due to these reasons considering stock-bond correlation in emerging markets is more important for investors point of view, risk management, asset allocation in a portfolio and it's helpful for investors for predicting correlation as higher financial market uncertainty leads to positive correlation otherwise indicate negative correlation 


\section{Trend Analysis}

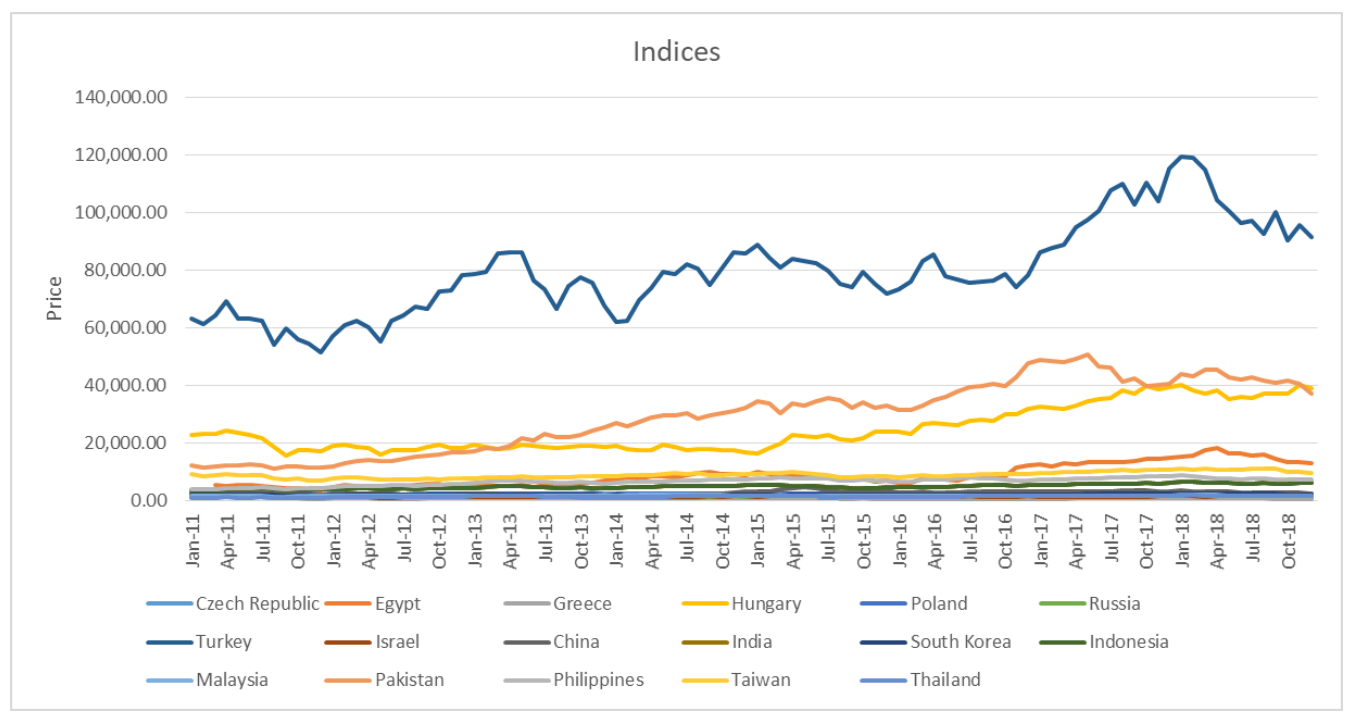

Figure 1. Emerging Market from 17 Countries Indices Price Fluctuation

In figure 1 Turkey exhibits the highest price fluctuation of index amongst other countries because it possesses political risk i.e. civil war in Syria as Turkey is a neighbor country and Iraq and Syria border link with Turkey and they are facing war against ISIS and currency risk i.e. lira is falling and current account deficit extend while Pakistan and Hungary both have also larger price volatility remaining to other countries which means investor's earning in those countries indices investment is higher if they take advantage of the market information and it is also observe the same pattern follows by all index of emerging country. If emerging market is bearish position investor's investment is riskier because all countries index prices is fallen or vice versa.

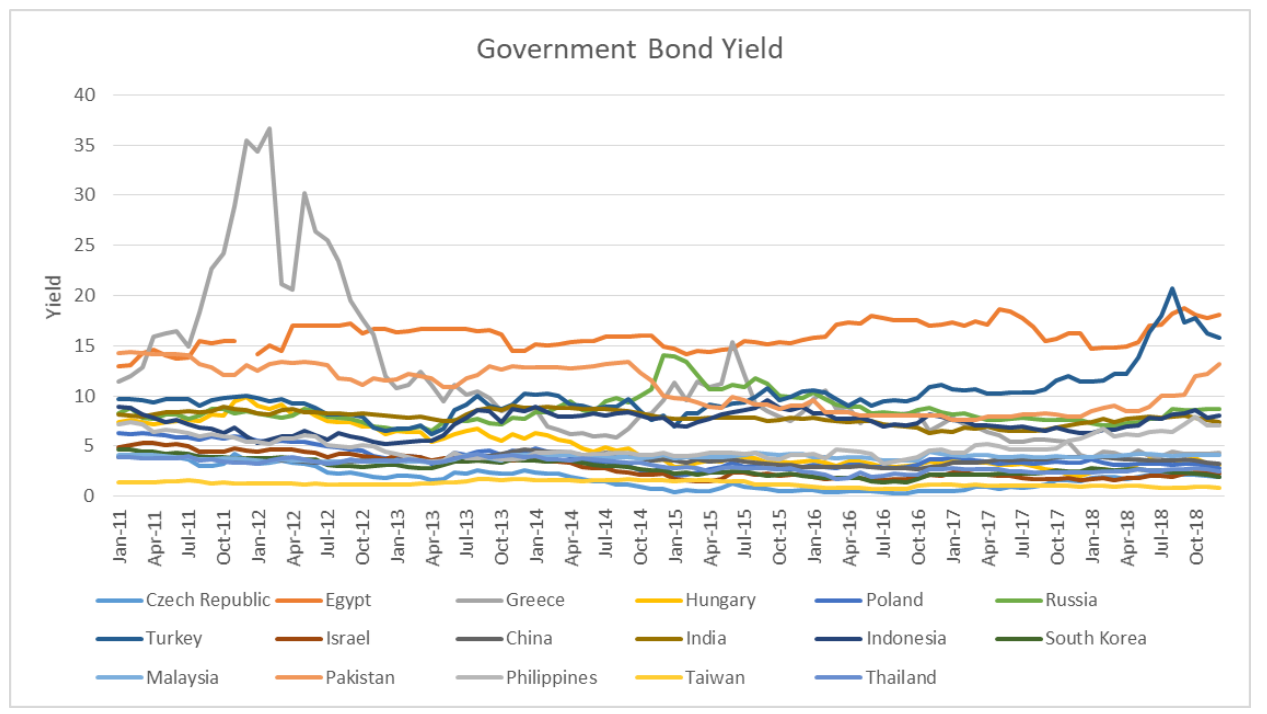

Figure 2. Emerging Market from 17 Countries Long Term 10 yr Bond Yield 


\section{Ml Macrothink}

In figure 2 Greece 10 year bond yield during January 2011 to January 2013 has a greater upward movement in 10 year yield, which shows during that period, country suffered from greater risk. The reason behind is Greece is facing Eurozone debt crisis which has badly affected its economy and has defaulted on debt and after some period of time it has recovered from this situation and stabilized their yield. Egypt and Pakistan both have higher yield to offer higher return for taking higher risk but Pakistan has slightly lower yield to gain investor's confidence in the economy. Overall emerging market countries 10 year yield shows slight fluctuation of uncertainty in the economy.

Hence emerging market are fast growing economies and it can be predicted that it can promote the world economy by around $42 \%$ and only China's contribution will be $27 \%$ to the rest of the world and anticipated growth rate of five year will be $3.5 \%$ because different geographical heterogeneity makes diversification easy. Emerging market complications is to have so much foreign debt and the recovery of their debt is quite difficult because of low earnings which cause currency depreciation (Aizpún, 2019).

\section{Descriptive Statistic}

Following tables 1 and 2 both show descriptive statistics of 17 countries from emerging markets from 2011 to 2018 of monthly data.

Table 1. Emerging Countries Descriptive Statistics of Indices

\begin{tabular}{|c|c|c|c|c|c|c|c|c|c|}
\hline \multicolumn{10}{|c|}{ INDICES } \\
\hline Country & Czech & Egypt & Greece & Hungary & Poland & Russia & Turkey & Israel & China \\
\hline & Republic & & & & & & & & \\
\hline Mean & 1001.82 & 8702.81 & 852.54 & 24653.73 & 2299.81 & 1741.89 & 79813.45 & 1373.48 & 2765.70 \\
\hline Standard & 9.51 & 390.56 & 25.95 & 794.39 & 26.18 & 33.22 & 1590.93 & 16.80 & 58.24 \\
\hline \multicolumn{10}{|l|}{ Error } \\
\hline Median & 989.83 & 7805.03 & 797.52 & 21760.53 & 2323.72 & 1667.80 & 78173.55 & 1403.87 & 2752.78 \\
\hline Mode & \#N/A & \#N/A & \#N/A & \#N/A & \#N/A & \#N/A & \#N/A & \#N/A & \#N/A \\
\hline Standard & 93.13 & 3806.74 & 252.94 & 7783.38 & 256.46 & 325.51 & 15587.85 & 164.59 & 570.63 \\
\hline \multicolumn{10}{|l|}{ Deviation } \\
\hline Sample & 8673.51 & 14491243.73 & 63977.62 & 60580997.43 & 65773.96 & 105953.90 & 242981042.34 & 27089.27 & 325613.34 \\
\hline \multicolumn{10}{|l|}{ Variance } \\
\hline Kurtosis & 1.10 & -0.58 & 0.63 & -0.92 & 0.34 & -0.86 & -0.02 & -0.75 & 0.50 \\
\hline Skewness & 0.92 & 0.78 & 1.10 & 0.78 & -0.32 & 0.58 & 0.56 & -0.17 & 0.68 \\
\hline Range & 444.09 & 14673.22 & 1076.59 & 24413.41 & 1203.62 & 1169.35 & 68262.17 & 654.98 & 2632.53 \\
\hline Minimum & 816.91 & 3622.35 & 516.71 & 15775.10 & 1709.51 & 1306.01 & 51266.62 & 1057.63 & 1979.21 \\
\hline Maximum & 1261.00 & 18295.57 & 1593.30 & 40188.51 & 2913.13 & 2475.36 & 119528.79 & 1712.61 & 4611.74 \\
\hline Sum & 96174.85 & 826766.76 & 80991.61 & 2366757.60 & 220781.34 & 167221.27 & 7662090.72 & 131854.21 & 265507.63 \\
\hline
\end{tabular}




\begin{tabular}{|c|c|c|c|c|c|c|c|c|}
\hline Country & India & Indonesia & $\begin{array}{l}\text { South } \\
\text { Korea }\end{array}$ & Malaysia & Pakistan & Philippines & Taiwan & Thailand \\
\hline Mean & 25120.34 & 4903.43 & 2069.55 & 1702.57 & 29454.07 & 6628.83 & 8947.94 & 1426.52 \\
\hline Standard & 639.77 & 80.03 & 18.39 & 11.56 & 1232.00 & 129.61 & 111.87 & 22.38 \\
\hline \multicolumn{9}{|l|}{ Error } \\
\hline Median & 26131.61 & 4861.98 & 2012.69 & 1700.21 & 31248.29 & 6987.02 & 8820.36 & 1463.05 \\
\hline Mode & \#N/A & \#N/A & 1912.06 & \#N/A & \#N/A & \#N/A & \#N/A & \#N/A \\
\hline Standard & 6268.42 & 784.13 & 180.17 & 113.24 & 12071.12 & 1269.91 & 1096.13 & 219.32 \\
\hline \multicolumn{9}{|l|}{ Deviation } \\
\hline Sample & 39293033.81 & 614856.99 & 32461.64 & 12823.94 & 145712024.16 & 1612673.83 & 1201497.96 & 48100.28 \\
\hline \multicolumn{9}{|l|}{ Variance } \\
\hline Kurtosis & -1.03 & -0.84 & 0.56 & -0.41 & -1.27 & -0.48 & -0.73 & -0.44 \\
\hline Skewness & 0.28 & 0.14 & 1.18 & -0.38 & -0.11 & -0.73 & 0.29 & -0.46 \\
\hline Range & 23190.15 & 3196.46 & 796.81 & 495.58 & 39520.99 & 4997.28 & 4199.67 & 913.92 \\
\hline Minimum & 15454.92 & 3409.17 & 1769.65 & 1387.13 & 11070.58 & 3766.73 & 6904.12 & 916.21 \\
\hline Maximum & 38645.07 & 6605.63 & 2566.46 & 1882.71 & 50591.57 & 8764.01 & 11103.79 & 1830.13 \\
\hline Sum & 2411552.54 & 470728.90 & 198677.17 & 163446.58 & 2827591.13 & 636367.56 & 859001.82 & 136945.72 \\
\hline
\end{tabular}

Table 2. Emerging Countries of descriptive statistics of 10 year Government Bond

\begin{tabular}{|c|c|c|c|c|c|c|c|c|c|}
\hline \multicolumn{10}{|c|}{ GOVERNMENT BOND YIELD } \\
\hline Country & Czech & Egypt & Greece & Hungary & Poland & Russia & Turkey & Israel & China \\
\hline \multicolumn{10}{|c|}{ Republic } \\
\hline Mean & 1.7872 & 16.0281 & 11.0969 & 4.9408 & 3.8720 & 8.5870 & 10.0664 & 2.9310 & 3.6013 \\
\hline Standard & 0.1120 & 0.1324 & 0.7512 & 0.2111 & 0.1133 & 0.1516 & 0.2538 & 0.1202 & 0.0429 \\
\hline \multicolumn{10}{|l|}{ Error } \\
\hline Median & 1.8280 & 15.9800 & 8.6180 & 3.7900 & 3.4390 & 8.2600 & 9.6700 & 2.3485 & 3.5845 \\
\hline Mode & 3.2060 & 15.5000 & 6.9520 & 7.4900 & 2.9450 & 7.7100 & 9.6700 & 3.6400 & 3.6000 \\
\hline Standard & 1.0972 & 1.2904 & 7.3599 & 2.0686 & 1.1096 & 1.4853 & 2.4870 & 1.1773 & 0.4203 \\
\hline \multicolumn{10}{|l|}{ Deviation } \\
\hline Sample & 1.2037 & 1.6652 & 54.1684 & 4.2789 & 1.2313 & 2.2060 & 6.1853 & 1.3861 & 0.1767 \\
\hline \multicolumn{10}{|l|}{ Variance } \\
\hline Kurtosis & -0.6904 & -0.6769 & 2.8010 & -0.9124 & -0.4744 & 3.4446 & 5.2121 & -1.2220 & -0.0161 \\
\hline Skewness & 0.4929 & -0.0608 & 1.7523 & 0.6162 & 0.7830 & 1.7114 & 2.0115 & 0.5146 & 0.0738 \\
\hline Range & 4.0040 & 5.7200 & 32.8570 & 7.8500 & 4.3440 & 7.5600 & 14.5300 & 3.8130 & 1.8860 \\
\hline Minimum & 0.2500 & 13.0000 & 3.7340 & 2.0900 & 1.9960 & 6.5300 & 6.1700 & 1.5070 & 2.7440 \\
\hline Maximum & 4.2540 & 18.7200 & 36.5910 & 9.9400 & 6.3400 & 14.0900 & 20.7000 & 5.3200 & 4.6300 \\
\hline Sum & 171.5680 & 1522.6670 & 1065.2980 & 474.3200 & 371.7140 & 824.3540 & 966.3700 & 281.3770 & 345.7240 \\
\hline
\end{tabular}




\begin{tabular}{|c|c|c|c|c|c|c|c|c|}
\hline Country & India & Indonesia & $\begin{array}{l}\text { South } \\
\text { Korea }\end{array}$ & Malaysia & Pakistan & Philippines & Taiwan & Thailand \\
\hline Mean & 7.8529 & 7.3292 & 2.8427 & 3.8922 & 10.7577 & 4.9433 & 1.2424 & 3.0756 \\
\hline Standard Error & 0.0686 & 0.1056 & 0.0815 & 0.0255 & 0.2249 & 0.1135 & 0.0284 & 0.0643 \\
\hline Median & 7.8600 & 7.4390 & 2.7030 & 3.9245 & 11.0090 & 4.5510 & 1.2100 & 2.9350 \\
\hline Mode & 7.4490 & \#N/A & 4.4800 & 4.0820 & 8.0270 & 5.9190 & 1.0400 & 2.7800 \\
\hline Standard & 0.6720 & 1.0347 & 0.7981 & 0.2503 & 2.2035 & 1.1125 & 0.2785 & 0.6297 \\
\hline \multicolumn{9}{|l|}{ Deviation } \\
\hline Sample Variance & 0.4516 & 1.0707 & 0.6369 & 0.0627 & 4.8552 & 1.2376 & 0.0776 & 0.3965 \\
\hline Kurtosis & -0.4104 & -0.7585 & -0.6152 & -0.8169 & -1.5503 & -0.4608 & -1.0229 & -1.2145 \\
\hline Skewness & -0.4613 & -0.2752 & 0.3783 & -0.3539 & 0.0250 & 0.7315 & -0.0009 & -0.0579 \\
\hline Range & 2.8140 & 4.4570 & 3.3220 & 1.0540 & 6.8090 & 4.7030 & 1.0850 & 2.5450 \\
\hline Minimum & 6.2460 & 5.1670 & 1.3880 & 3.3700 & 7.5900 & 3.2470 & 0.6750 & 1.7300 \\
\hline Maximum & 9.0600 & 9.6240 & 4.7100 & 4.4240 & 14.3990 & 7.9500 & 1.7600 & 4.2750 \\
\hline Sum & 753.8830 & 703.6040 & 272.9030 & 373.6480 & 1032.7370 & 474.5540 & 119.2660 & 295.2620 \\
\hline
\end{tabular}

\section{Methodology}

To examine the co-movement or correlation of stock-bond of emerging countries two step methodology is established, first is construction of univariate asymmetric GARCH and the second step involves analysis of multivariate extended GARCH model i.e. ADCC

Financial market known for volatility clustering is captured by Engle model of "Autoregressive Conditional Heteroscedasticity (ARCH)" which means yesterday's volatility explains tomorrow volatility and it is time varying conditional variance property. The ARCH (q) model equation is given below

$$
\begin{gathered}
\mathrm{r}_{\mathrm{t}}=\mu_{\mathrm{t}}+\mathrm{y}_{\mathrm{t}} \\
\mathrm{y}_{\mathrm{t}}=\sqrt{h} t \quad \mathrm{z}_{\mathrm{t}(\text { note } 1)} \\
\mathrm{h}_{\mathrm{t}}=\omega+\sum_{i=1}^{q} \alpha \quad \mathrm{y}_{\mathrm{t}-\mathrm{i}}^{2}
\end{gathered}
$$

ARCH model extension introduced by Bollerslev known as General Autoregressive Conditional Heteroscedasticity $(\mathrm{GARCH})$ analyzes heteroscedasticity in financial time series past squared returns and also describe past conditional variances and it is more flexible than ARCH model. Its equation can be defined as

$$
\mathrm{h}_{\mathrm{t}}=\omega+\sum_{i=1}^{p} \alpha \mathrm{y}_{\mathrm{t}-\mathrm{I}}^{2}+\sum_{i=1}^{q} \beta \mathrm{h}_{\mathrm{t}-\mathrm{i}(\text { note } 2)}
$$




\section{Al Macrothink}

In this equation conditional variance i.e. $h_{t}$ describe by not only for past squared returns but also for past conditional variance(note 3 ).

To add leverage effect caused by good news and bad news and for analyzing financial market there is an extended version of the GARCH model called (Lawrence R Glosten, 1993) find that inverse relation between expected return and conditional volatility and this model explain that positive and negative variation having reverse effect on conditional variance. Following is the equation of the model

$$
\mathrm{h}_{\mathrm{t}}=\omega+\sum_{i=1}^{p} \alpha_{1} \mathrm{y}^{2} \mathrm{t}-1+\sum_{i=1}^{p} \delta_{1} \mathrm{l}_{\mathrm{i}}\left[\mathrm{y}_{\mathrm{t}-\mathrm{i}}<0\right] \mathrm{y}_{\mathrm{t}-\mathrm{l}}^{2}+\sum_{i=1}^{q} \beta_{\mathrm{l}} \mathrm{h}_{\mathrm{t}-\mathrm{i}}
$$

Hence,

If there is any existence of leverage effect as a result of bad news impact on $(\alpha+\delta)$ i.e. $\delta>0$. In case of good news effecting $\alpha$ as a result of positive shocks.

$$
\mathrm{I}_{\mathrm{i}}\left[\mathrm{y}_{\mathrm{t}-\mathrm{I}}<0\right]=\left\{\begin{array}{l}
1 \text { if } y_{t-I}<0 \\
0 \text { if } y_{t-I} \geq 0
\end{array}\right.
$$

Univariate GARCH model used for considering individual asset volatility analysis. However, examine assets covariance and their co-movements multivariate GARCH is most useful for this purposes. In a portfolio, assets move together and their prices are dependent varying over time and having financial market volatilities. Univariate GARCH can be defined in above equation (1), (2) and (4)

(Kevin Sheppard, 2001) Introducing DCC model through using S\&P-500 indices and Dow Jones Industrial Average for investigating conditional covariance between assets with null hypothesis constant correlation against an alternative of Dynamic Conditional Correlation (DCC) and the purpose of this model for enabling time varying conditional correlation and extended version of this model is Asymmetric Dynamic Conditional Correlation (ADCC) GARCH established by (Lorenzo Cappiello, 2006) to examine correlation of equity indices and government bonds of European countries and obtain that adverse news in the market more influences conditional volatility of equity indices than government bonds and when in time of financial downturn volatility of equity market increases more rapidly as compared with government bonds whereas financial crisis effect both equity market and government bonds. So adding asymmetric impact on the correlation model happening by good news or bad news circumstances to capture the combine volatility of stock and bond. Its equation is incorporate with conditional covariance matrix and conditional standard deviation it can be defined as

$$
H_{t}=D_{t} R_{t} D_{t(\text { note } 4)}
$$

Since DCC model is, 


$$
\begin{gathered}
\mathrm{R}_{\mathrm{t}}=\mathrm{Q}_{\mathrm{t}}{ }^{*}-1 \mathrm{Q}_{\mathrm{t}} \mathrm{Q}_{\mathrm{t}}{ }^{*}-1 \\
\mathrm{Q}_{\mathrm{t}}=(1-\mathrm{a}-\mathrm{b}) \mathrm{Q}+\mathrm{a} \overline{\epsilon_{t-1}} \epsilon_{\mathrm{t}-1}{ }^{\top}+\mathrm{b} \mathrm{Q}_{\mathrm{t}-1 \text { (note } 5)}
\end{gathered}
$$

Therefore,

$$
\bar{Q}=\frac{1}{T} \sum_{t=1}^{T} \epsilon_{\mathrm{t}} \epsilon_{\mathrm{t}}^{\top}
$$

Whereas $\mathrm{Q}_{\mathrm{t}}{ }^{*}$ is the diagonal matrix

$$
\begin{gathered}
\mathrm{Q}_{\mathrm{t}}{ }^{*}=\left[\begin{array}{ccc}
\sqrt{q} 11 t & \cdots & 0 \\
\vdots & \ddots & \vdots \\
0 & \cdots & \sqrt{q n n t}
\end{array}\right] \text { (note 6) } \\
|\rho i j|=\left|\frac{\text { qijt }}{\sqrt{\text { qiit } q j j t}}\right| \leq 1
\end{gathered}
$$

Following are the conditions of the DCC model should hold

$$
\alpha \geq 0, \beta \geq 0 \text { and } \alpha+\beta<1
$$

The extension of version DCC model by adding asymmetric effect and it is created by Cappiello et al. (2006)

$$
\mathrm{Q}_{\mathrm{t}}=\left(\bar{Q}-\mathrm{A}^{\prime} \bar{Q} \mathrm{~A}-\mathrm{B}^{\prime} \bar{Q} \mathrm{~B}-\mathrm{G}^{\prime} \bar{N} \mathrm{G}\right)+\mathrm{A}^{\prime} \epsilon_{\mathrm{t}} \epsilon_{\mathrm{t}-1}^{\prime} \mathrm{A}+\mathrm{B}^{\prime} \mathrm{Q}_{\mathrm{t}-1} \mathrm{~B}+\mathrm{G}^{\prime} \mathrm{n}_{\mathrm{t}-1} \mathrm{n}_{\mathrm{t}-1}^{\prime} \mathrm{G}(\text { note } 7)
$$

Where,

$$
\begin{gathered}
\mathrm{n}_{\mathrm{t}}=I\left[\epsilon_{\mathrm{t}}<0\right] \circ \epsilon_{\mathrm{t}} \rightarrow \circ=\text { Hadamard product } \\
\text { Ii }\left[y_{t-I}<0\right]=\left\{\begin{array}{l}
1 \quad \text { if } y_{t-I}<0 \\
0 \text { if } y_{t-I} \geq 0
\end{array}\right.
\end{gathered}
$$

ADCC model condition if $Q_{t}$ is positive definite

$$
Q-A A^{\prime} \circ B B^{\prime} \circ Q-G G^{\prime} \circ N
$$




\section{Macrothink}

By simplifying the above equation through replacing the coefficient i.e. A, B and $\mathrm{G}$ to scalars $\sqrt{a}, \sqrt{b}$ and $\sqrt{g}$ so the equation can be revised as

$$
\mathrm{Q}_{\mathrm{t}}=(\bar{Q}-\mathrm{a} \bar{Q}-\mathrm{b} \bar{Q}-\mathrm{g} \bar{N})+\mathrm{a} \epsilon_{\mathrm{t}-1} \epsilon_{\mathrm{t}-1}^{\prime}+\mathrm{bQ}_{\mathrm{t}-1}+\mathrm{gn}_{\mathrm{t}-1} \mathrm{n}_{\mathrm{t}-1(\text { note } 8)}
$$

\section{Results}

In this paper, monthly prices of indices and bonds of 17 of emerging market namely: Czech Republic, Egypt, Greece, Hungary, Poland, Russia, Turkey, Israel, China, India, Indonesia, South Korea, Malaysia, Pakistan, Philippines, Taiwan, Thailand for sample period during January 2011 to December 2018 are considered. Data has been gathered from investing.com. To find out returns of stocks (Indices, 2019) and bonds of 10 years (World Government Bonds, 2019) $\log$ differences of their prices are used.

\subsection{Hypothesis}

$\mathrm{H}_{\mathrm{o}}$ : Countries in emerging markets indices and government bonds does not have co-movement.

$\mathrm{H}_{\mathrm{a}}$ : Countries in emerging markets indices and government bonds have co-movement.
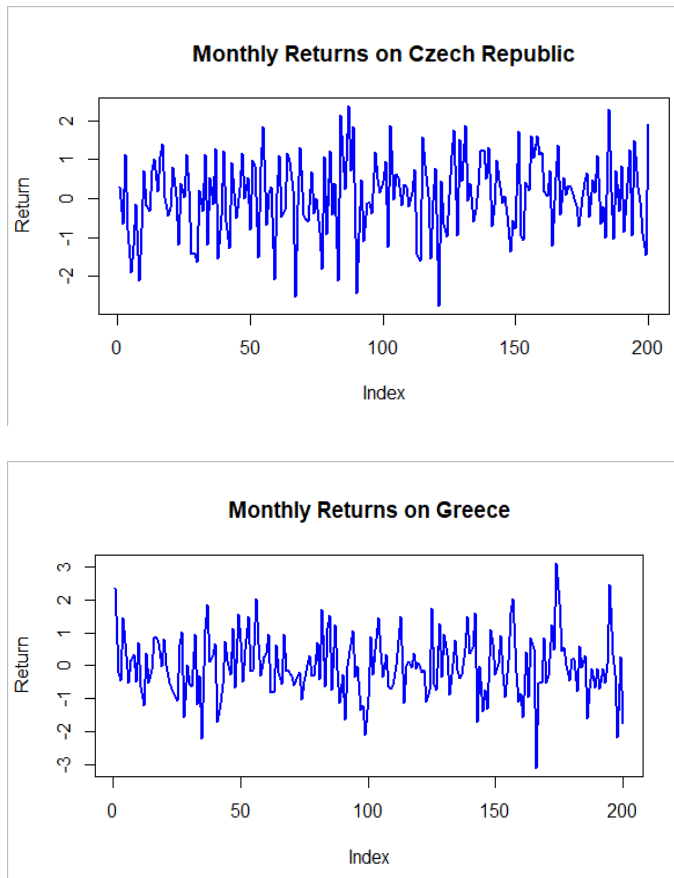
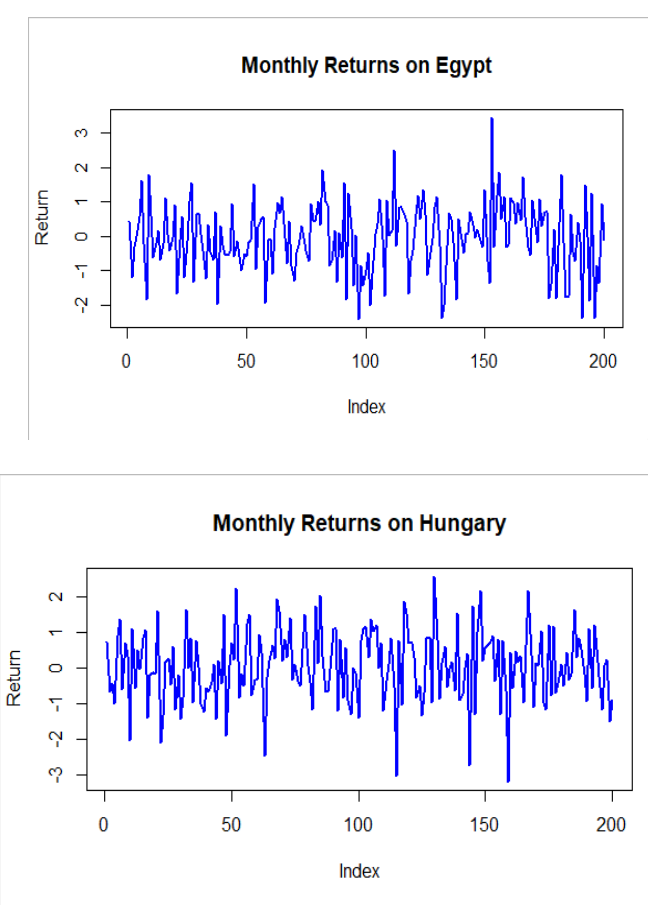


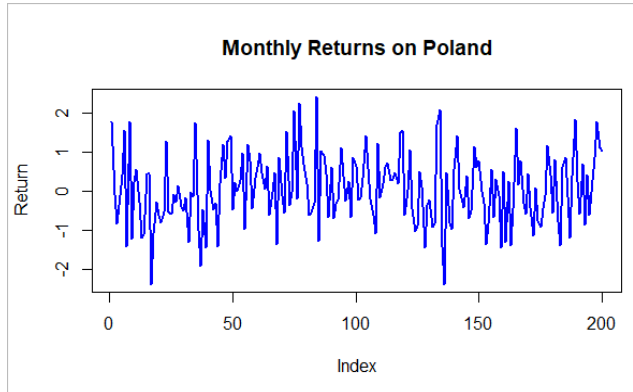

Monthly Returns on Turkey
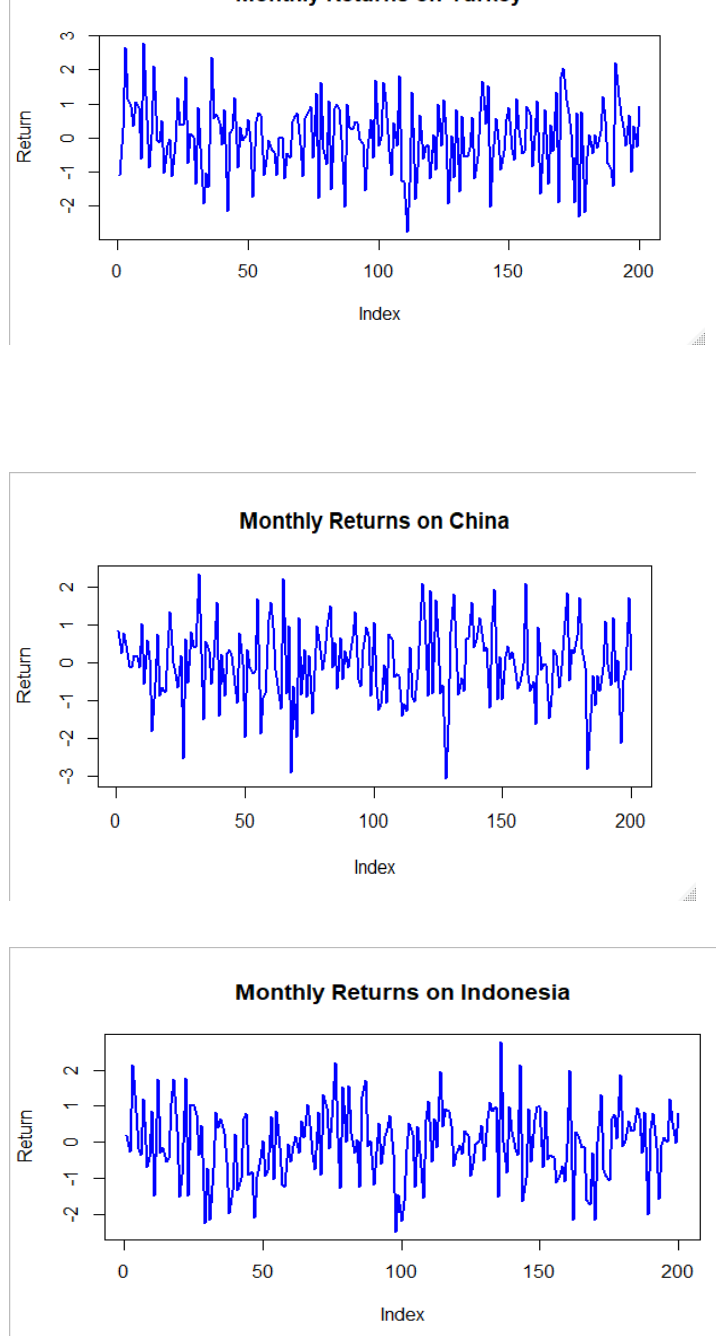
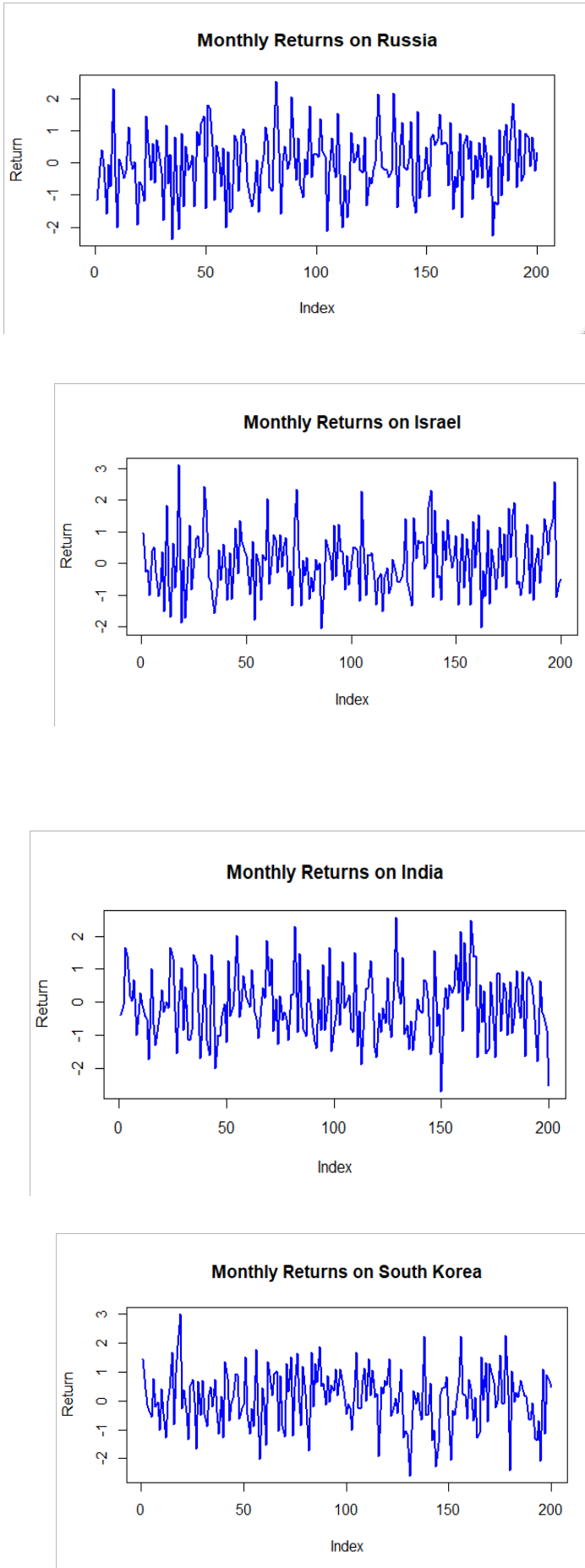

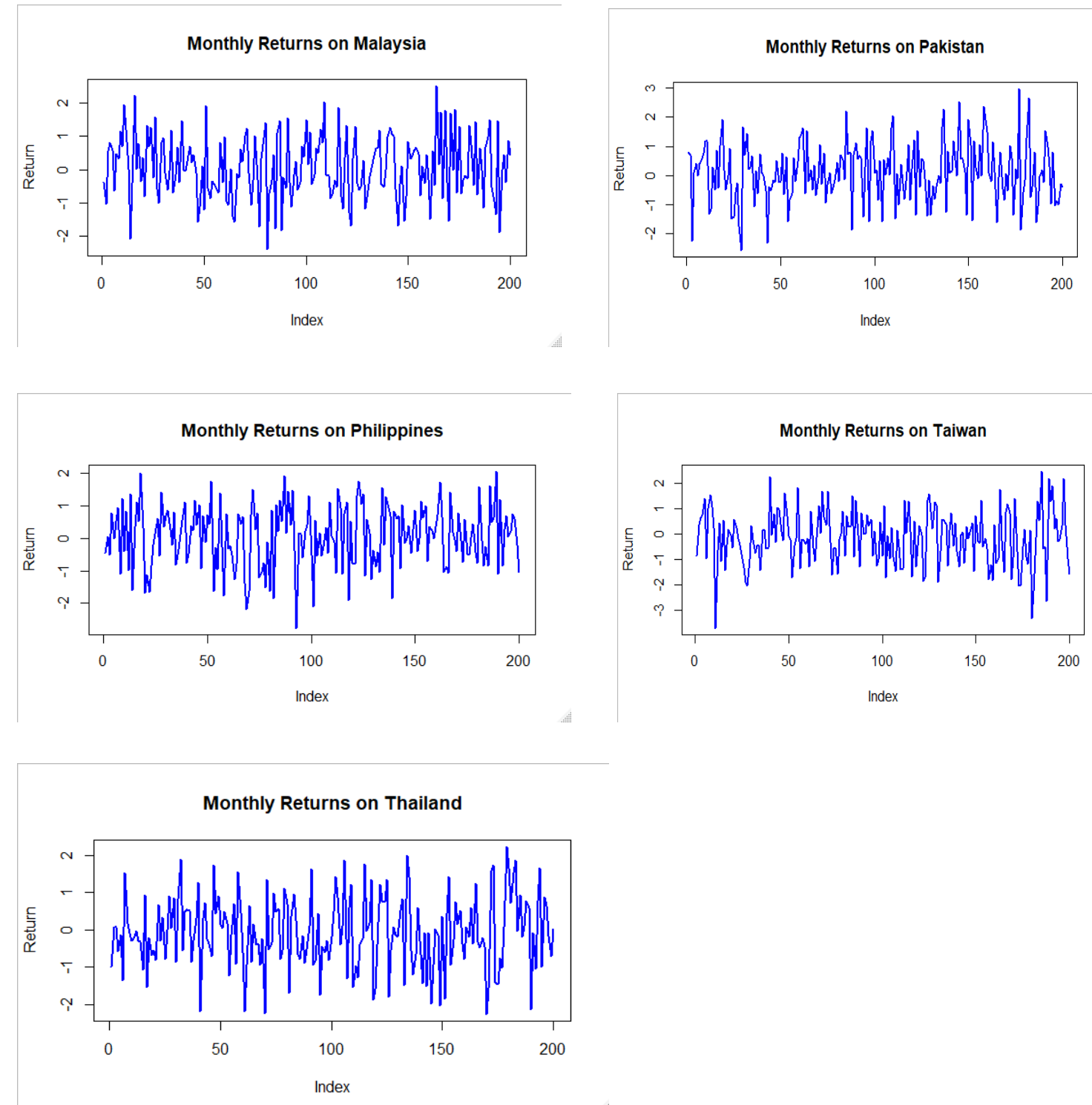

Figure 3. Stocks Return 

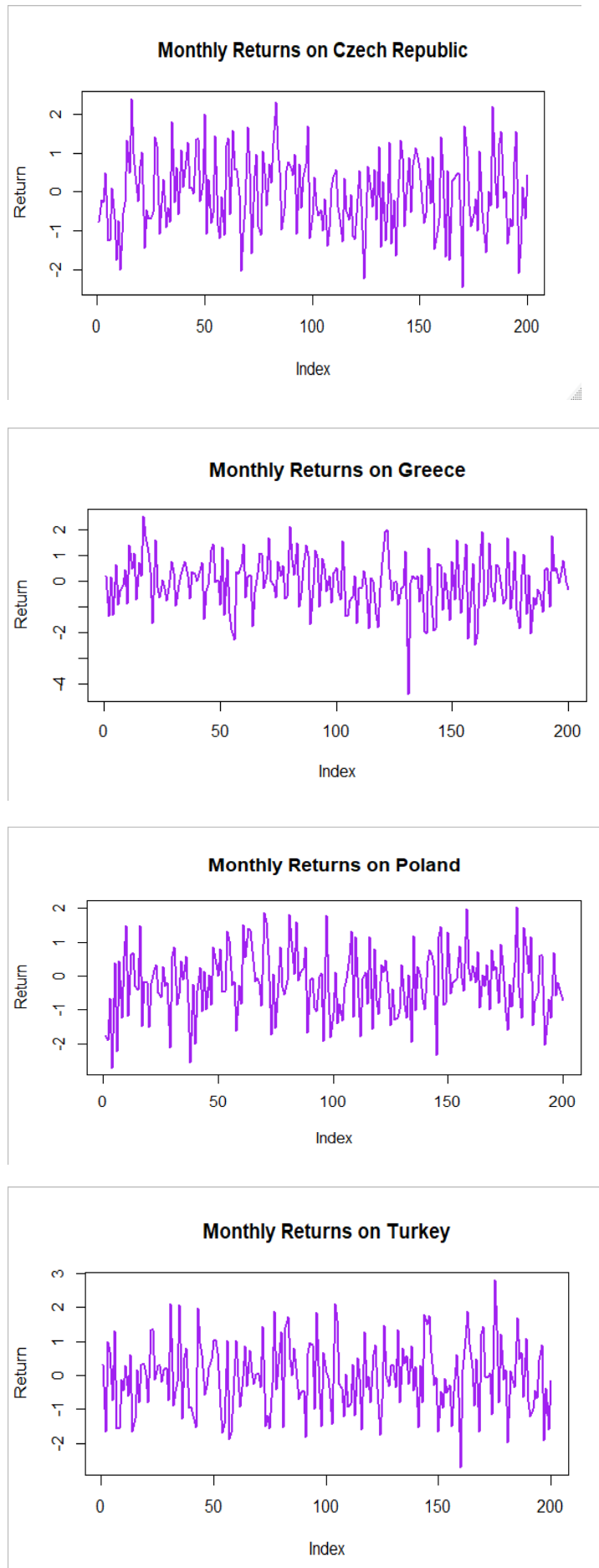
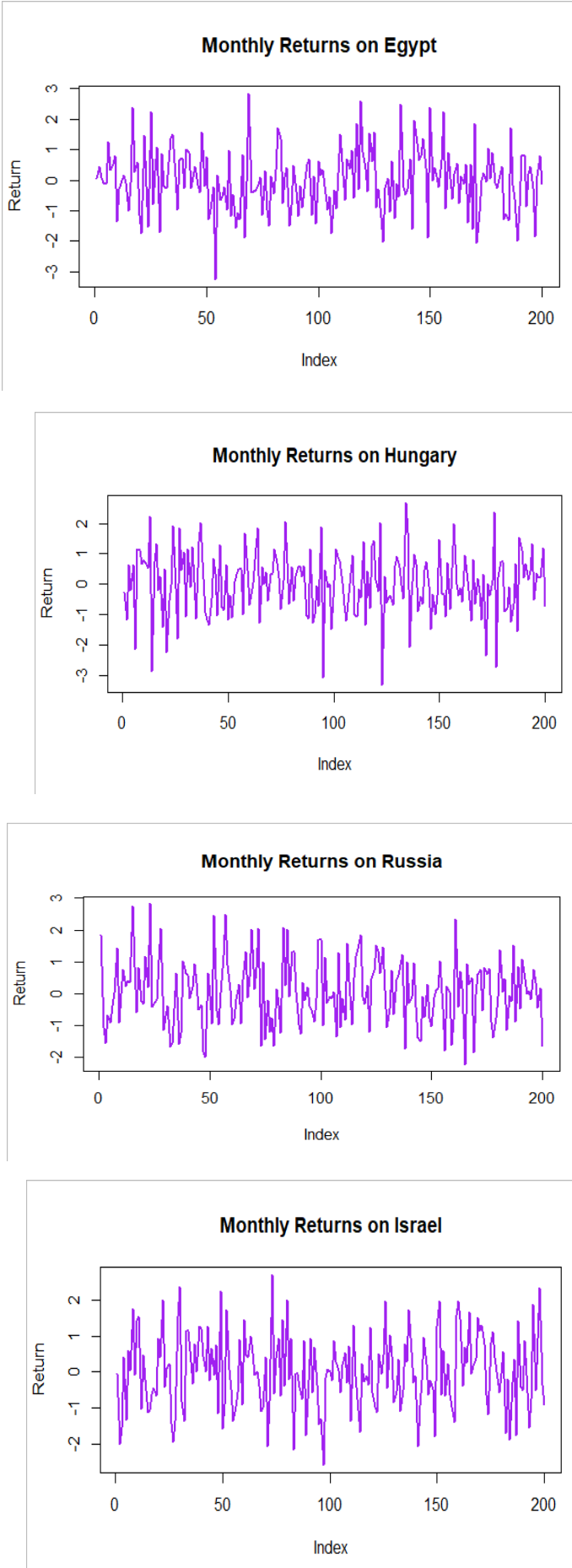

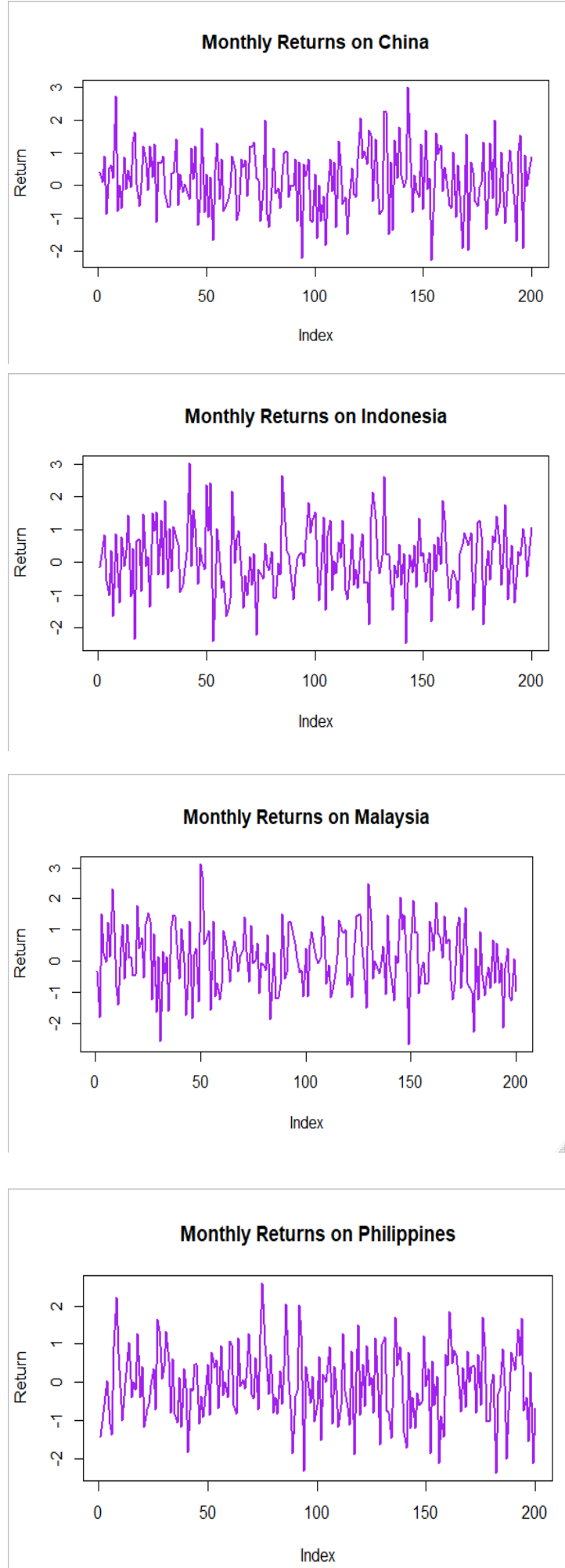

Monthly Returns on India

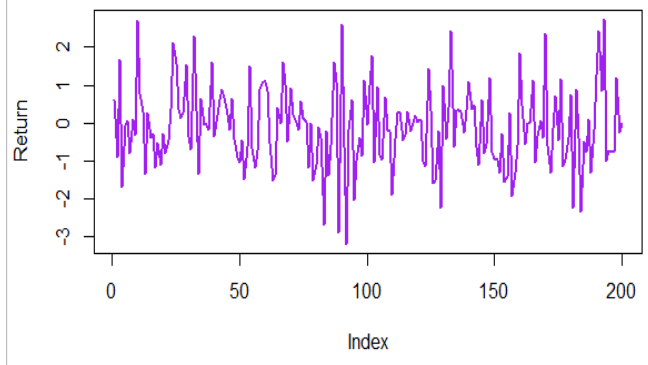

Monthly Returns on South Korea
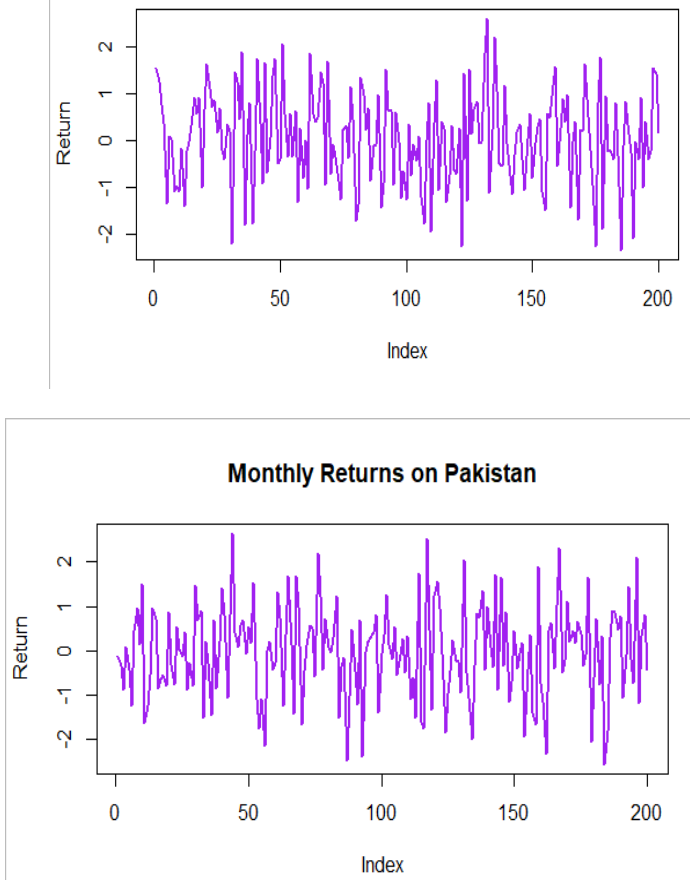

Monthly Returns on Taiwan

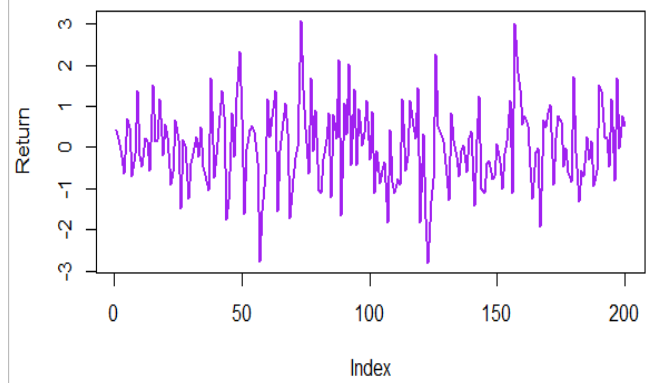




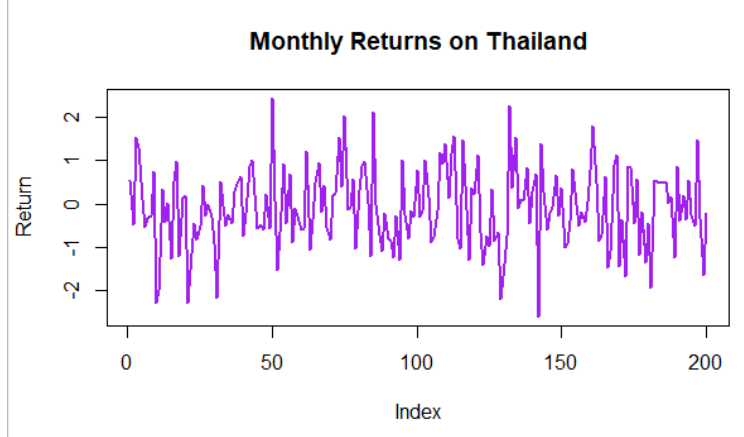

Figure 4. Bonds Return

In Fig: 3 and 4 it shows that stock indices and government bonds return are stationary, mean reverting and exhibit volatility clustering. ARCH-LM test proposed that past information having potential to predict future variances (Engle, 1982) model using to detect sequence of return series having heteroscedasiticity either holding white noise error or capturing volatility clustering. In table $3 \mathrm{p}$ value of ARCH-LM test is greater than 0.05 except for South Korea Bond. Hence, countries having white noise error so the sequence of the series is unpredictable and residuals having least heteroscedasticity.

Table 3. ARCH-LM Test

\begin{tabular}{|c|c|c|c|c|c|c|c|c|}
\hline \multicolumn{9}{|c|}{ ARCH-LM Test } \\
\hline \multirow{2}{*}{$\begin{array}{l}\text { Country } \\
\text { d.f }=12\end{array}$} & \multicolumn{2}{|c|}{ Czech Republic } & \multicolumn{2}{|c|}{ Egypt } & \multicolumn{2}{|c|}{ Greece } & \multicolumn{2}{|c|}{ Hungary } \\
\hline & Bond & Stock & Bond & Stock & Bond & Stock & Bond & Stock \\
\hline P-value & 0.6105 & 0.1947 & 0.3474 & 0.7940 & 0.7296 & 0.1734 & 0.1376 & 0.6107 \\
\hline Chi-squared & 10.0630 & 15.9250 & 13.3030 & 7.8852 & 8.6851 & 16.4040 & 17.3310 & 10.0600 \\
\hline Country & \multicolumn{2}{|c|}{ Poland } & \multicolumn{2}{|c|}{ Russia } & \multicolumn{2}{|c|}{ Turkey } & \multicolumn{2}{|c|}{ Israel } \\
\hline d.f $=12$ & Bond & Stock & Bond & Stock & Bond & Stock & Bond & Stock \\
\hline $\mathrm{P}$-value & 0.8277 & 0.5245 & 0.4483 & 0.4715 & 0.5006 & 0.5794 & 0.9299 & 0.7424 \\
\hline Chi-squared & 7.4333 & 11.0510 & 11.9680 & 11.6820 & 11.3330 & 10.4180 & 5.7129 & 8.5310 \\
\hline Country & \multicolumn{2}{|c|}{ China } & \multicolumn{2}{|c|}{ India } & \multicolumn{2}{|c|}{ Indonesia } & \multicolumn{2}{|c|}{ South Korea } \\
\hline d. $f=12$ & Bond & Stock & Bond & Stock & Bond & Stock & Bond & Stock \\
\hline $\mathrm{P}$-value & 0.0831 & 0.8405 & 0.0732 & 0.8322 & 0.6577 & 0.8017 & 0.0408 & 0.9803 \\
\hline Chi-squared & 19.2310 & 7.2524 & 19.6900 & 7.3706 & 9.5229 & 7.7844 & 21.7180 & 4.1634 \\
\hline Country & \multicolumn{2}{|c|}{ Malaysia } & \multicolumn{2}{|c|}{ Pakistan } & \multicolumn{2}{|c|}{ Philippines } & \multicolumn{2}{|c|}{ Taiwan } \\
\hline d. $f=12$ & Bond & Stock & Bond & Stock & Bond & Stock & Bond & Stock \\
\hline $\mathrm{P}$-value & 0.3636 & 0.3635 & 0.8928 & 0.1397 & 0.3783 & 0.2514 & 0.8713 & 0.4626 \\
\hline Chi-squared & 13.0750 & 13.0760 & 6.4307 & 17.2710 & 12.8730 & 14.8210 & 6.7875 & 11.7910 \\
\hline Country & \multicolumn{2}{|c|}{ Thailand } & & & & & & \\
\hline d. $f=12$ & Bond & Stock & & & & & & \\
\hline $\mathrm{P}$-value & 0.4514 & 0.6189 & & & & & & \\
\hline Chi-squared & 11.9280 & 9.9670 & & & & & & \\
\hline
\end{tabular}




\section{Al Macrothink}

Research in Applied Economics

ISSN 1948-5433 2019, Vol. 11, No. 3

To analyze past volatilities that predict future volatilities in the return series univariate asymmetric GARCH i.e. GJR-GARCH is constructed. There are three parameters i.e. $\alpha, \beta$, and $\delta$ and can be defined as the component of past return volatilities, past variance volatilities and asymmetric effect reacting for good news or bad news in the market respectively. As seen in table 4(note 9): high mean of government bond recorded of countries Indonesia (0.113236) and China (0.162100) shows high performance over the sample period 2011 to 2018. Similarly, for stock indices Pakistan has high mean value i.e. 0.115629. Most of countries values of $\alpha$ nearly zero so past squared return volatilities do not predict tomorrow's volatility whereas in contrast $\beta$ values are huge showing that yesterday's variance volatility predict future variance volatility . Taiwan bond have large value of asymmetric effect $\delta=0.055795$ which means negative shocks increase the volatility similarly for index of Greece i.e. $\delta=0.058034$. Therefore positive shocks decrease the volatility.

Table 4. Asymmetric GARCH

\begin{tabular}{|c|c|c|c|c|c|c|c|c|}
\hline \multicolumn{9}{|c|}{ GJR-GARCH } \\
\hline Estimates & Czech Republic & Egypt & Greece & Hungary & Poland & Russia & Turkey & Israel \\
\hline \multirow[t]{2}{*}{$\mu^{\mathrm{b}}$} & 0.006398 & -0.054331 & -0.082619 & 0.053668 & -0.183455 & 0.073312 & -0.009449 & 0.025008 \\
\hline & 0.936190 & 0.506120 & 0.267610 & 0.520665 & 0.008375 & 0.305611 & 0.850006 & 0.728760 \\
\hline \multirow[t]{2}{*}{$\omega^{\mathrm{b}}$} & 0.046057 & 0.032186 & 0.002217 & 0.020798 & 0.025743 & 0.007622 & 0.040306 & 0.023191 \\
\hline & 0.600640 & 0.296810 & 0.736500 & 0.000208 & 0.448001 & 0.559764 & 0.000000 & 0.198200 \\
\hline \multirow[t]{2}{*}{$\alpha^{\mathrm{b}}$} & 0.011861 & 0.000000 & 0.000000 & 0.000000 & 0.000000 & 0.004083 & 0.000000 & 0.000000 \\
\hline & 0.730830 & 1.000000 & 1.000000 & 0.999982 & 1.000000 & 0.792580 & 1.000000 & 1.000000 \\
\hline \multirow[t]{2}{*}{$\beta^{\mathrm{b}}$} & 0.938777 & 1.000000 & 1.000000 & 1.000000 & 0.977431 & 1.000000 & 1.000000 & 1.000000 \\
\hline & 0.000000 & 0.000000 & 0.000000 & 0.000000 & 0.000000 & 0.000000 & 0.000000 & 0.000000 \\
\hline \multirow[t]{2}{*}{$\delta^{\mathrm{b}}$} & 0.026181 & -0.051306 & -0.003232 & -0.034580 & -0.011809 & -0.026306 & -0.078798 & -0.043520 \\
\hline & 0.697220 & 0.000000 & 0.636220 & 0.026385 & 0.702591 & 0.003694 & 0.000000 & 0.135570 \\
\hline \multirow[t]{2}{*}{$\mu^{\mathrm{s}}$} & 0.080508 & -0.045724 & -0.008380 & 0.078184 & 0.053520 & -0.018971 & 0.004082 & 0.054046 \\
\hline & 0.251840 & 0.520440 & 0.881434 & 0.260070 & 0.340530 & 0.792920 & 0.955445 & 0.465363 \\
\hline \multirow[t]{2}{*}{$\omega^{\mathrm{s}}$} & 0.090935 & 0.002397 & 0.058856 & 0.033296 & 0.004995 & 0.000438 & 0.057089 & 0.019698 \\
\hline & 0.397200 & 0.847490 & 0.277616 & 0.000000 & 0.568000 & 0.981090 & 0.025542 & 0.020184 \\
\hline \multirow[t]{2}{*}{$\alpha^{\mathrm{s}}$} & 0.000000 & 0.004544 & 0.000000 & 0.000000 & 0.000000 & 0.000000 & 0.000000 & 0.000000 \\
\hline & 1.000000 & 0.766050 & 1.000000 & 1.000000 & 1.000000 & 1.000000 & 1.000000 & 0.999972 \\
\hline \multirow[t]{2}{*}{$\beta^{\mathrm{s}}$} & 0.884473 & 0.996366 & 0.907741 & 1.000000 & 1.000000 & 0.998325 & 0.964484 & 1.000000 \\
\hline & 0.000000 & 0.000000 & 0.000000 & 0.000000 & 0.000000 & 0.000000 & 0.000000 & 0.000000 \\
\hline \multirow[t]{2}{*}{$\delta^{\mathrm{s}}$} & 0.045519 & -0.003820 & 0.058034 & -0.059113 & -0.013174 & 0.001350 & -0.036166 & -0.043659 \\
\hline & 0.555460 & 0.912870 & 0.078368 & 0.000000 & 0.310850 & 0.965830 & 0.093225 & 0.018481 \\
\hline
\end{tabular}


Table 4. Cont...

\begin{tabular}{|c|c|c|c|c|c|c|c|c|c|}
\hline \multicolumn{10}{|c|}{ GJR-GARCH } \\
\hline Estimates & China & India & Indonesia & $\begin{array}{l}\text { South } \\
\text { Korea }\end{array}$ & Malaysia & Pakistan & Philippines & Taiwan & Thailand \\
\hline \multirow[t]{2}{*}{$\mu^{\mathrm{b}}$} & 0.162100 & -0.109175 & 0.113236 & 0.058564 & 0.093508 & -0.020196 & -0.045647 & 0.027930 & -0.086393 \\
\hline & 0.018554 & 0.159200 & 0.117170 & 0.424110 & 0.200340 & 0.785750 & 0.493260 & 0.685180 & 0.176399 \\
\hline \multirow[t]{2}{*}{$\omega^{\mathrm{b}}$} & 0.002815 & 0.001308 & 0.022185 & 0.003905 & 0.010265 & 0.008400 & 0.002851 & 0.050893 & 0.018942 \\
\hline & 0.812895 & 0.947450 & 0.000000 & 0.847400 & 0.313850 & 0.524340 & 0.821870 & 0.649130 & 0.000004 \\
\hline \multirow[t]{2}{*}{$\alpha^{\mathrm{b}}$} & 0.000000 & 0.000000 & 0.004433 & 0.000000 & 0.000000 & 0.000000 & 0.000000 & 0.000000 & 0.000000 \\
\hline & 1.000000 & 1.000000 & 0.095820 & 1.000000 & 0.999980 & 0.999990 & 1.000000 & 1.000000 & 1.000000 \\
\hline \multirow[t]{2}{*}{$\beta^{\mathrm{b}}$} & 0.989774 & 0.999959 & 1.000000 & 0.999999 & 1.000000 & 1.000000 & 1.000000 & 0.923143 & 0.999461 \\
\hline & 0.000000 & 0.000000 & 0.000000 & 0.000000 & 0.000000 & 0.000000 & 0.000000 & 0.000000 & 0.000000 \\
\hline \multirow[t]{2}{*}{$\delta^{\mathrm{b}}$} & 0.018452 & -0.001919 & -0.052170 & -0.007605 & -0.020833 & -0.014955 & -0.006299 & 0.055795 & -0.046126 \\
\hline & 0.634756 & 0.945360 & 0.000000 & 0.783050 & 0.272390 & 0.622050 & 0.364790 & 0.344050 & 0.000002 \\
\hline \multirow[t]{2}{*}{$\mu^{\mathrm{s}}$} & -0.003935 & -0.093866 & -0.040892 & 0.076023 & 0.086088 & 0.115629 & 0.073450 & -0.139958 & -0.067720 \\
\hline & 0.955675 & 0.185390 & 0.787377 & 0.261680 & 0.201400 & 0.098136 & 0.254568 & 0.085264 & 0.323440 \\
\hline \multirow[t]{2}{*}{$\omega^{\mathrm{s}}$} & 0.021100 & 0.007543 & 0.025253 & 0.002270 & 0.013117 & 0.022338 & 0.030784 & 0.024445 & 0.002262 \\
\hline & 0.045371 & 0.662390 & 0.150610 & 0.812560 & 0.372170 & 0.001996 & 0.086576 & 0.813932 & 0.837180 \\
\hline \multirow[t]{2}{*}{$\alpha^{\mathrm{s}}$} & 0.000000 & 0.000000 & 0.000000 & 0.000000 & 0.000000 & 0.000000 & 0.000000 & 0.000000 & 0.001376 \\
\hline & 0.999988 & 1.000000 & 1.000000 & 1.000000 & 0.999990 & 0.999995 & 0.999999 & 0.999999 & 0.965290 \\
\hline \multirow[t]{2}{*}{$\beta^{\mathrm{s}}$} & 1.000000 & 1.000000 & 1.000000 & 1.000000 & 1.000000 & 1.000000 & 0.952754 & 0.961104 & 0.994685 \\
\hline & 0.000000 & 0.000000 & 0.000000 & 0.000000 & 0.000000 & 0.000000 & 0.000000 & 0.000000 & 0.000000 \\
\hline \multirow[t]{2}{*}{$\delta^{\mathrm{s}}$} & -0.040771 & -0.016908 & -0.049003 & -0.004609 & -0.029053 & -0.042346 & 0.022620 & 0.034268 & 0.005879 \\
\hline & 0.026418 & 0.696240 & 0.074629 & 0.819790 & 0.383850 & 0.001382 & 0.066027 & 0.735532 & 0.907830 \\
\hline
\end{tabular}

In the last step the stock and bond co-movement of stock and bond is examined simultaneously build multivariate GARCH model type of asymmetric DCC model for this purpose. In table 5(note 10) a, b and g coefficient defined as combination of bivariate impact of previous market shocks, conditional correlation and co-movement in response to positive or negative news in the market respectively. For stationary conditions $a+b+g<1$. As seen in table 5 negative shocks in the market (i.e. g) increase the co-movement of stocks and bond returns and past shocks (i.e. a) having least impact on bivariate of stocks and bonds. 
Table 5. Multivariate GARCH

\begin{tabular}{|c|c|c|c|c|c|c|c|c|}
\hline \multicolumn{9}{|c|}{ A-DCC Multivariate GARCH } \\
\hline Estimates & Czech Republic & Egypt & Greece & Hungary & Poland & Russia & Turkey & Israel \\
\hline \multirow[t]{2}{*}{$\mathrm{a}$} & 0.013045 & 0.042985 & 0.000000 & 0.045134 & 0.000000 & 0.000000 & 0.000000 & 0.000000 \\
\hline & 0.931720 & 0.227000 & 1.000000 & 0.176571 & 1.000000 & 1.000000 & 1.000000 & 1.000000 \\
\hline \multirow[t]{2}{*}{$\mathrm{b}$} & 0.736419 & 0.825628 & 0.964965 & 0.850383 & 0.943796 & 0.916801 & 0.926719 & 0.999002 \\
\hline & 0.375720 & 0.000000 & 0.000000 & 0.000017 & 0.000000 & 0.000000 & 0.000000 & 0.000000 \\
\hline \multirow[t]{2}{*}{$\mathrm{g}$} & 0.070502 & 0.043514 & 0.000000 & 0.000000 & 0.000000 & 0.000000 & 0.000000 & 0.002970 \\
\hline & 0.849090 & 0.648520 & 0.999994 & 1.000000 & 0.999997 & 1.000000 & 0.999999 & 0.741231 \\
\hline Estimates & China & India & Indonesia & South Korea & Malaysia & Pakistan & Philippines & Taiwan \\
\hline \multirow[t]{2}{*}{ a } & 0.017791 & 0.000000 & 0.000000 & 0.008403 & 0.000000 & 0.000000 & 0.019098 & 0.069516 \\
\hline & 0.804824 & 0.999998 & 0.999999 & 0.659100 & 1.000000 & 1.000000 & 0.450282 & 0.256744 \\
\hline \multirow[t]{2}{*}{$\mathrm{b}$} & 0.692083 & 0.933936 & 0.998460 & 0.951982 & 0.931885 & 0.607583 & 0.928732 & 0.750236 \\
\hline & 0.003576 & 0.000000 & 0.000000 & 0.000000 & 0.000000 & 0.796409 & 0.000000 & 0.024322 \\
\hline \multirow[t]{2}{*}{$\mathrm{g}$} & 0.098291 & 0.000000 & 0.004352 & 0.000000 & 0.000000 & 0.127996 & 0.003945 & 0.000000 \\
\hline & 0.660030 & 1.000000 & 0.727432 & 1.000000 & 1.000000 & 0.891403 & 0.905973 & 0.999999 \\
\hline Estimates & Thailand & & & & & & & \\
\hline \multirow[t]{2}{*}{$\mathrm{a}$} & 0.000000 & & & & & & & \\
\hline & 1.000000 & & & & & & & \\
\hline \multirow[t]{2}{*}{ b } & 0.927904 & & & & & & & \\
\hline & 0.000000 & & & & & & & \\
\hline \multirow[t]{2}{*}{$\mathrm{g}$} & 0.000000 & & & & & & & \\
\hline & 0.999999 & & & & & & & \\
\hline
\end{tabular}

\section{Discussions}

The study analyzed that return series have white noise error and it is uncorrelated and unpredictable while possessing stationary feature and found that GARCH conditions hold so it anticipated past variation predict future variations and asymmetric GARCH impact in emerging countries effect both assets i.e. stocks and bond but stocks reacted most rapidly than bonds when investigating combine asymmetric influences. It is established that unfavorable momentum increases the correlation and reduces the diversification advantage and bonds hedging ability to stocks is not applicable while favorable momentum decreases the correlation and encourage diversification and consistent with "flight to quality" phenomena and these detection similarity with the research analysis of (Lorenzo Cappiello, 2006) and construct that equity index volatility have more impact than bond index conditional volatility with specific news in the market especially in adverse situation like financial market crash event occur in 87,Gulf war and Asia market crash and correlation of assets increases in sectors where heterogeneity benefited the investors and diversification easing is reduced when it is demanded by investors during the crisis period and decrease the correlation by investors with using strategy of taking short position i.e. selling the assets. Furthermore, EMU suggest that after January 1999 introduction of exchange rate causing exact correlation and exhibit 
diversification profitability to transfer assets from Europe to US.

Another article results (DU, 2017) contradict to our findings and conclude that time varying stock bond correlation estimate conditional stock bond correlation. Dividend and inflation rate used to describe conditional stock-bond correlation with the help of non-identical bond maturities. Endogenous consumption volatility cause conditional stock-bond correlation to convert the sign from positive to negative. Investor's risk averse of asset allocation expectation regarding change of economic growth and inflation did not impact on conditional stock bond correlation rather than anticipating heterogeneous risk for outlook of economy and inflation switching stock-bond correlation.

(Belen Nieto, 2015) Analyzed stock-bond correlation price transaction of the same firm and these type of data set are rare and investigate solely stock and bond return correlation for achieving target level of leverage adjustment over a period of time for capital composition selection. Their research determine that correlation between them is very small and for low liquidity bonds major impact by dynamic in correlation through applying non trading adjustment and persistence models and results indicate that macroeconomic variable does not effect on correlation while fluctuation of consumption growth of firms and default premium on bonds increases which decline the correlation and measures of firm specific risk. It is also reason of changes in the sign of the correlation and it is concluded that greater the correlation between the firms, higher probability of reaching target level of leverage and these detections are opposite of results in the paper.

There is another article which investigates correlation about European stock and government bonds (Erica R. Perego, 2016) and found that macroeconomic variables such as inflation, debt level and monetary policy of Euro zone countries derives stock bond correlation and divide Euro zone into two areas i.e. northern and southern to identify the divergence effect and found that northern region "secure assets" in risky area correlated with "risky assets" in secure area similar with southern region and correlation between assets is determined through future cash flow predictions of the region. Heterogeneity of economic indicators is one of the factors that derive financial market uncertainty. Hence, these results are not consistent with research findings.

Stock-bond correlation is also investigated through anticipation of macroeconomic variables by (Conrad \& Loch, 2016) and the study established that over long period of time economic inflation and changes of interest rate in three months in the economy and financial market fluctuation derive stock bond correlation and it is beneficial for analyzing business cycle and predicting correlation over that period of time and asset selection in a portfolio and managing risk and monetary policy directed by central bank for easing and tightening the monetary policy effect stock-bond correlation and causes enlargement of correlation risk in a portfolio and asymmetric effect can be seen in Eurozone for managing portfolio risk and determination of the paper results does not consistent with this study.

(Baur, 2010) Examine cross country stock-bond co-movements and determined that stock bond co-movement domination in cross country and little correlation in all developed countries lead to lessen the diversification and often cause asset reallocation in a portfolio and it's used as an 
alternate to neutralize the effect low diversification benefit and found that US dominate returns of stock and bond market and these results also contradict to research of the paper.

\section{Conclusion}

In this paper investigating the stock and bond correlation in emerging markets of 17 countries from 2011 to 2018 of monthly data and it's essential to understanding trend analysis of the data and found that all countries follow the same pattern in the response to economic fluctuation except few countries which shows higher prices and yield that compensate with taking risk e.g. Greece suffering low liquidity in debt influencing higher rate of interest in bonds and Turkey distressed with political and economic situation that hits it's stock market.

For the purpose of analyzing co-movement of stocks and bonds first inspect the returns hold stationary conditions through ARCH-LM test and in the second step applying univariate GJRGARCH model then in the last using Multivariate GARCH technique i.e. ADCC model.

The finding of the results are; stocks and bond return having white noise error as in the ARCHLM test $p$ value is greater than 0.05 and it can shows that returns are mean averting and returns series are unpredictable to future variation. For examine the individual impact of stock and bond in response to specific news in the market using technique of asymmetric GARCH (GJR GARCH) for adding leverage effect and it shows that past squared return having lower ability to predict future squared return $(\alpha)$ while past conditional variance values are large $(\beta)$ and asymmetric effect negative impact increase the volatility $(\delta)$. Countries possessing higher volatility with the reaction of the news roaming around the market and it can be noted that bond impact is less than index volatility of a country as bonds consider to safer assets because these countries are considered to be member of developing market and uncertainty is higher as compared with developed market. For bivariate analysis using the ADCC model and their results can be explained as past shocks (a) having slightest impact on both variables, dynamic conditional correlation (b) showing higher conditional volatility and negative momentum in the market increases the correlation of stock and bond and positive momentum decreases the correlation $(\mathrm{g})$. It can also explain that for combine analysis of stock and bond there is mixture of favorable and unfavorable momentum among countries of emerging markets.

Hence, through these results conclude that countries in emerging market having greater financial uncertainty and countries facing economic and political uncertainty that will not helpful for predicting past return volatilities to future volatility both stock and bond market possessing volatilities and reacting with the news in the market while considering the comovement of stock and bond having substantial conditional volatility and positive shocks occur in one country in contrast there is higher probability of negative momentum in another country of emerging market and it can evidence that greater diversification benefit provided among countries and consistent with "flight to quality" phenomena and it is advantageous for hedging assets among countries but showing positive correlation of individual countries stock and bonds and it's suggest that there is co-movement of stock and bond when assessing countries in an isolation from emerging markets . 


\section{Macrothink}

\section{References}

Aizpún, F. C. (2019). Emerging markets: The silver lining amid a challenging outlook. Swiss Re Institue.

Baur, D. G. (2010). Stock-bond co-movements and cross-country linkages. International Journal of Banking, Accounting and Finance, 2(2), 111-129. https://doi.org/10.1504/IJBAAF.2010.032848

Belen Nieto, R. R. (2015). Corporate Stock and Bond Return Correlations and Dynamic Adjustments of Capital Structure. Journal of Business Finance and Accounting, 42(5-6), 705-746. https://doi.org/10.1111/jbfa.12114

Conrad, C., \& Loch, K. (2016). Macroeconomic expectations and the time-varying stock-bond correlation : international evidence. ECONSTAR.

DU, J. (2017). On the Time-varying Stock-Bond Correlation: Deciphering Heterogenous Expectations. European Financial Management Association.

Engle, R. F. (1982). Autoregressive Conditional Heteroscedasticity with Estimates of the Variance of United Kingdom Inflation. Econometrica, 50(4), 987-1007. https://doi.org/10.2307/1912773

Erica R. Perego, W. N. (2016). Macro-economic determinants of European stock and government bond correlations: A tale of two regions. Journal of Empirical Finance, 37, 214-232. https://doi.org/10.1016/j.jempfin.2016.04.002

Fu-Lai Lin, S.-Y. Y.-F. (2018). Stock and bond return relations and stock market uncertainty: Evidence from wavelet analysis. International Review of Economics and Finance, 55, 285-294. https://doi.org/10.1016/j.iref.2017.07.013

Harumi Ohmi, T. O. (2015). Trends in stock-bond correlations. Applied Economics, 48(6), 536552. https://doi.org/10.1080/00036846.2015.1083088

Hossein Asgharian, C. C. (2015). Effects of macroeconomic uncertainty on the stock and bond markets. Finance Research Letters, 13, 10-16. https://doi.org/10.1016/j.frl.2015.03.008

Hossein Asgharian, C. C. (2016). Macro-Finance Determinants of the Long-Run Stock-Bond Correlation: The DCC-MIDAS Specification. Journal of Financial Econometrics, 617642.

Idil, E. R. (2014). A Century of Stock-Bond Correlations. Reserve Bank of Australia, 67-74.

Indices. (2019, March). Retrieved from Investing.com: https://www.investing.com/indices/

Jian Yang, Y. Z. (2009). The stock-bond correlation and macroeconomic conditions: One and a half centuries of evidence. Journal of Banking and Finance, 33(4), 670-680. https://doi.org/10.1016/j.jbankfin.2008.11.010

Kevin Sheppard, R. F. (2001). Theoretical and Empirical Properties of Dynamic Conditional Correlation Multivariate GARCH. NBER Working Paper. 


\section{MIMacrothink}

Research in Applied Economics

ISSN 1948-5433

2019, Vol. 11, No. 3

Lawrence R Glosten, R. J. (1993). On the Relation between the Expected Value and the Volatility of the Nominal Excess Return on Stocks. Journal of Finance, 48(5), 1779-1801. https://doi.org/10.1111/j.1540-6261.1993.tb05128.x

Libing Fang, H. Y. (2018). The role of investor sentimentin the long term correlation between U.S. stock and bond markets. International Review of Economics and Finance, 58, $127-$ 139. https://doi.org/10.1016/j.iref.2018.03.005

Lieven Baele, G. B. (2010). The Determinants of Stock and Bond Return Comovements. The Review of Financial Studies, 23(6), 2374-2428. https://doi.org/10.1093/rfs/hhq014

Lorenzo Cappiello, R. F. (2006). Asymmetric Dynamics in the Correlations of Global Equity and Bond Returns. Journal of Financial Econometrics, 537-572. https://doi.org/10.1093/jjfinec/nbl005

Magnus Andersson, E. K. (2008). Why does the correlation between stock and bond returns vary over time. Applied Financial Economics, 18(2), 139-151. https://doi.org/10.1080/09603100601057854

Malcom Baker, J. W. (2006). Investor Sentiment and the Cross - Section of Stock Returns. The Journal of Finance, 61(4), 1645-1680. https://doi.org/10.1111/j.15406261.2006.00885.x

Marcelo Bianconi, J. A. (2013). BRIC and the U.S. financial crisis: An empirical investigation of stock and bond markets. Emerging Markets Review, 14, 76-109. https://doi.org/10.1016/j.ememar.2012.11.002

McMillan, D. G. (2018). The information content of the stock and bond return correlation. Quantitative Finance and Economics, 2(3), 757-775. https://doi.org/10.3934/QFE.2018.3.757

Nathaniel Frank, H. H. (2009). Financial Spillovers to Emerging Markets During the Global Financial Crisis. International Monetary Fund. https://doi.org/10.5089/9781451872514.001

Nebojsa Dimic, J. K. (2016). Impact of financial market uncertainty and macroeconomicfactors on stock-bond correlation in emerging markets. Research in International Business and Finance, 36, 41-51. https://doi.org/10.1016/j.ribaf.2015.09.001

Nektarios Aslanidis, C. C. (2012). Smooth transition patterns in the realized stock-bond correlation. Journal of Empirical Finance, 19(4), 454-464. https://doi.org/10.1016/j.jempfin.2012.04.005

Okimoto, H. O. (2016). Trends in stock-bond correlations. Applied Economics, 48(6), 536-552. https://doi.org/10.1080/00036846.2015.1083088

Peter Christoffersen, V. E. (2012). Is the Potential for International Diversification Disappearing? A Dynamic Copula Approach. Review of Financial Studies, 25(12), 37113751. https://doi.org/10.1093/rfs/hhs104 
Robert Connolly, C. S. (2005). Stock Market Uncertainty and the Stock-Bond Return Relation. JOURNAL OF FINANCIAL AND QUANTITATIVE ANALYSIS, 40(1), 161-194. https://doi.org/10.1017/S0022109000001782

Thomas C. Chiang, J. L. (2009). The Dynamic Correlation Between Stock and Bond Returns. SSRN Electronic Journal, 43. https://doi.org/10.2139/ssrn.1362225

Thomas C. Chiang, J. L.-Y. (2015). Dynamic stock-bond return correlations and financial market uncertainty. Review of Quantitative Finance and Accounting, 59-88.

Tobin, J. (1982). Money and Finance in the Macroeconomic Process. Journal of Money, Credit and Banking, 14(2), 171-204. https://doi.org/10.2307/1991638

Valentyn Panchenko, E. W. (2009). Time-varying market integration and stock and bond return concordance in emerging markets. Journal of Banking and Finance, 33(6), 1014-1021. https://doi.org/10.1016/j.jbankfin.2008.10.016

World Government Bonds. (2019, March). Retrieved from Investing.com: https://www.investing.com/rates-bonds/world-governmentbonds?maturity_from $=10 \&$ maturity_to $=180$

Xia-Ming Li, B. Z. (2015). Economic policy uncertainty shocks and stock-bond correlations: Evidence from the US market. Economic Letters, 132, 91-96. https://doi.org/10.1016/j.econlet.2015.04.013

Yardeni, D. E. (1997). Fed's Stock Market Model Finds Overvaluation. US Equity.

\section{Notes}

Note $1 . z_{t}$ is independent with mean zero and variance one

Note 2. For holding stationary condition $\alpha+\beta<1$

Note 3. $h_{\mathrm{t}}>0$ if $\alpha_{\mathrm{i}}, \beta_{\mathrm{i}} \geq 0$

Note 4. $\mathrm{D}_{\mathrm{t}}=\operatorname{diag}\left(\mathrm{h}_{1 \mathrm{t}}{ }^{1 / 2}, \ldots, \mathrm{h}_{\mathrm{nt}}{ }^{1 / 2}\right) \rightarrow$ Conditional Standard Deviation $\mathrm{R}_{\mathrm{t}}=$ Correlation matrix

Note 5. $\bar{Q}=\operatorname{Cov}\left[\epsilon_{\mathrm{t}} \epsilon_{\mathrm{t}}^{\mathrm{T}}\right]=\mathrm{E}\left[\epsilon_{\mathrm{t}} \epsilon_{\mathrm{t}}^{\mathrm{T}}\right] \rightarrow$ unconditional covariance matrix, $\epsilon_{\mathrm{t}} \rightarrow$ standardized residuals

Note 6. $\mathrm{Q}_{\mathrm{t}}{ }^{*}=$ diagonal matrix of square root of diagonal elements of $\mathrm{Q}_{\mathrm{t}}$

Note 7. A,B and $\mathrm{G}$ are parameters of diagonal matrices

Note $8 . \mathrm{a}+\mathrm{b}+\delta \mathrm{g}<1$

Note 9. Table 4: estimates co-efficient showing two values e.g: $\mu=0.006398$ parameter and 0.93619 significance at $5 \%$ etc. $b=$ Bonds, $s=$ Stocks. For holding stationary conditions $\alpha+\beta$ $+\delta \leq 1$

Note 10 . Table 5 : estimates co-efficient showing two values e.g: $\mathrm{a}=0.013045$ parameter and 0.931720 s significance at $5 \%$ 


\section{Macrothink}

\section{Copyright Disclaimer}

Copyright for this article is retained by the author(s), with first publication rights granted to the journal.

This is an open-access article distributed under the terms and conditions of the Creative Commons Attribution license (http://creativecommons.org/licenses/by/3.0/). 